\title{
Blindness in Seeing: A Philosophical Critique of the Visible Learning Paradigm in Education
}

\author{
Steen Nepper Larsen 1 \\ Danish School of Education, Aarhus University, 2400 Copenhagen NV, Denmark; stla@edu.au.dk; \\ Tel.: +45-50-58-33-80
}

Received: 26 November 2018; Accepted: 19 February 2019; Published: 28 February 2019

\begin{abstract}
An international consensus seems to have developed in educational research-and among educational planners and policymakers-during the last 10-15 years proclaiming that learning is, and must be, a visible phenomenon. This paper questions this predominant view and serves an assemblage of points offering educational scientists at least four profound perspectives to reflect upon. First of all, learning is not immediately visible to the learning subject. It demands and deserves a qualitative lifelong perspective and-not to be underestimated-autonomous reflections to come to know and acknowledge what learning is and can be in an existential perspective. For the individual, it is always worth asking the question whether or not the things 'learned' in the first place were worth learning. Secondly, no one can examine the complex synaptic wiring process in the changeable and 'learning' brain (i.e., human neuroplasticity); the body-phenomenological depths and growth of a human being; or the manifold processes constituting the totality of historical social interactions surrounding the learning process and reduce them to something simple and already 'known' (a figure, a score, an effect, an answer in a test, an evaluation statement, etc). Thirdly, so-called visible learning for teachers has to be differentiated from both conscious and unconscious learning for pupils and students. The attempts to objectify and sometimes even instrumentalize learning risk running into obvious problems and fostering serious mistakes. Besides, the teacher and the 'learner' do not share the same perspectives and they often also have different interests. Fourthly, the concept of learning is not a value-neutral term and should only be used with an awareness of its historical development as a concept. I will argue that character formation-edification of character (Bildung), in light of the rich German geisteswissenschaftliche tradition-and the capability to think and become a vivid language user and creator demand much more than learning. Moreover, teaching is much more than a method to 'produce' learning, and to reproduce learning goals, and the purpose of education must transcend a teleological implementation of strategic national and international learning goals. In this paper, the revitalized concept of Bildung both serves as a critique of the visible learning paradigm and as a take-off of an alternative and more fertile way to conceptualize the task and possibilities of education. The line of the argument and ambition of the paper is to depict how blindness seems to be an inevitable part of educational seeing. The thesis is that powerful scientific and political adherents of learning cannot see what they cannot see-neither when they see what they (think they) see, nor when they do not see what they do not (want to) see.
\end{abstract}

Keywords: visible learning; blindness in seeing; critique; anti-reductionism; Bildung

\section{1. “Our Learning Is Visible"}

The giant black words are written on vast white cloth banners that adorn the tall yellow brick walls of Maglegård School in Gentofte, a leafy northern suburb of Copenhagen, Denmark ("Vores læring er synlig" in Danish). This popular municipal primary and lower secondary school—like many schools around the globe- has adopted a visible learning programme [1], and the school authorities seem 
to take for granted that grasping and, not least, demonstrating and promoting learning outcomes for parents, the local community, and local politicians is a mandatory task. Learning has become an ever-present concept in everyday language: a buzzword and an institutional and powerful strategic brand for competing schools.

Furthermore, learning has become an idealized mantra, a claim, an expectation, a social technology, and an integral part of educational governance and policy. In the latest school reform-adopted by the social democratic government and the majority of the other parties in the Danish parliament in 2014-nearly 3000 so-called "learning goals" were embedded in the curriculum for the different subjects. Students are expected to endeavour to achieve each of these goals with their progress tested regularly during the 10 years of compulsory schooling.

But is learning a visible phenomenon? What is learning, and for whom is and should learning be visible? It is certainly difficult to provide profound answers to these three questions. Often, they are not even presented as questions or discussed among school researchers, as many of them do honour 'the empirical turn' in education, much less are they open to public discussion. This lack of discussion is likely because many spokesmen for learning and professional agents within school systems consider the answers obvious and a foregone conclusion.

For the highly influential economic statistician John Hattie, who wrote the modern classic Visible Learning: A synthesis of over 800 meta-analyses relating to achievement [2], learning is a visible and countable phenomenon that preferably has to have an effect size of more than " 0.4 ". He wants not only to maximize but also to visualize the invisible. Thus, he paradoxically makes what was previously visible and obvious invisible, e.g., that the school is embedded in the national political machine; that social interaction in the classroom is not reducible to learning processes; and that schoolchildren are not just subjected to learning-now and then, they are taught something and may even think for themselves! Children can also play, be united in unconscious joint attention patterns and inter-human actions, daydream and cheat, maybe even engage in silent or manifest protest against the dominant learning strategies, thereby making way for learning skills that might prove important in the long run. It also needs to be mentioned that Hattie, who not only wants to develop visible learning strategies for teachers but also has ambitions of finding out how learning occurs 'inside' the learners, never actually talks to the learners. Neither does he deal with the long and contested history of the concept of learning [3]. He is definitely not working as a conceptual historian nor as a phenomenologist-even though he emphasizes that teachers have to show deep interest in understanding and reflecting upon how it feels to be a learner 'inside' a learning process. It is important to stress that Hattie himself does not provide politicians-eagerly looking for scientific legitimation for policy paper writing and school law enforcement-with strategic educational "learning goals" that can be inscribed and implemented in national curricula but he is often used-and abused [4-6] — this way.

According to the Danish professor in lifelong learning Knud Illeris, who has developed a useful and concise definition of the term, "learning can be broadly defined as a permanent change in capacities, not only due to oblivion, biological maturation or ageing". Often-but not always-learning is connected to deliberate interpretation, intention, and handling of the processes leading to a change in capacities, 'producing' new possibilities to act and think differently [7] (pp. 380-381). Learning does not just come from external sources; learning is always incarnated in the individual and has a specific expression. However, it is likely that learning also contains enigmatic elements that individuals can never come to understand in their own person or directly reconstruct in theories of learning [8]. At the same time, it is important to stress that learning is a contested concept in modern societies. More or less everyone is in favour of more learning even though few agree on a shared definition of the term.

It is my contention that the concept of learning has lost its credentials and become subordinate to a highly problematic effect-centred "learning outcome" logic that can be baptized "learnification" and which contributes to a relegation of teachers to a role as "facilitators of learning", as the educational philosopher Gert Biesta rightly proclaims [9] (pp. 2,23,27-29). To clarify my position, Illeris's definition of the term above can be taken as a jumping-off point. (Within the limited frame of this article, I will 
not be able to depict how Hattie's theory of learning differs from other predominant 20th and 21st century learning theories, nor answer the important question of why Hattie's work and his visible learning paradigm gained such ground in international educational politics. This explicit personal essay draws on philosophy, sociology, pedagogy, and the history of ideas (conceptual history) - and to make my own critical position clear, I have chosen not to tie to other critiques of Hattie's work).

My first philosophical argument is that learning can never be an instant, simple and visible phenomenon-neither for the teacher nor for the 'key figure', i.e., the learning subject. I would claim that in this very moment, you are potentially about to learn something; you do not know whether it will have a tiny influence or a major impact on your life 10 or 20 years later. It could be that you consider what happens in school at this very moment extremely dull or disturbing, and maybe even irritating. Oh, grammar, what is the point of that? Dusty old history books, social stratification studies, endless science classes ... Why do I have to care about these subjects? But, at some point down the line, what happened that particular date or that month or that year could prove very important. Therefore, learning cannot be comprehended as a visible phenomenon that can be grasped and depicted in the present (see also the exchanges with Hattie on this topic in [10]). Learning very seldom offers instant gratification and can never be understood nor lived independent(ly) of the dynamic interpretation of the ever-changing learning subject her or himself. It is a myth that learning is present and observable instantly in a moment and that it can be measured, exposed, and treated as a fixed object. It is worth remembering Illeris's key definition - that, in broad terms, learning can be defined as a permanent change in capacities-and acknowledging that the qualitative existential time factor (i.e., the individual phenomenological experience of time and meaning) and unique life experience are far more important than learning outcome figures, grade points and scores, and other 'snapshots'.

In October 2018, the conference "Improving Schools through an International Outlook" was held at the Danish School of Education in Copenhagen. Andreas Schleicher, director for the Directorate of Education and Skills, OECD, made a keynote presentation entitled: "Megatrends: Students' and teachers' future competencies. Recommendations for educational policy and practice" [11]. Schleicher outlined the long-term learning goals for future-oriented education and for pupils and students of tomorrow and proclaimed that it is far more important to learn to think like a mathematician or a sociologist than to give precise answers to closed test questions. Profound knowledge of a subject bears a strong resemblance to meta-learning and extends, e.g., the surface handling of multiple-choice tests [12] (Ch. 4). Deep learning is connected to the capability to come up with previously unheard of or unseen answers; it might even be said to require the courage to ask completely new and unanticipated questions that 'test' and challenge the teacher's privileged position, the logic of the exam, and the whole 'sacred' school system [13]. Understood in this light, learning does not concern something we ('the learning system') already know and are able to predict and measure in advance, nor does learning equate to an accumulation of form-similar knowledge bricks.

In 10 Mindframes for Visible Learning, Teaching for Success, Hattie and Zierer honestly state: "Consider the fact that only 20 percent of what happens in class is observable. The other 80 percent is not immediately apparent and, therefore, needs to be made visible. The teacher needs to know what the learners think about the pedagogical questions concerning goals, content, methods, and media to be able to plan the next lesson at all. Teachers who rely solely on their own impression run the risk of (no longer) reaching the learners." [14] (p. 90).

It is also important to note and dwell upon this potentially self-critical empirical memento, which clearly tells the reader and the educational practitioner that a maximum one-fifth of what happens in a school class is visible to the teacher. The given percentage is not backed up by arguments, evidence or references, even though it is highly questionable if the observing teacher can see what happens 'inside' the pupils (i.e., their brains, bodies, reflections, understandings, and unconscious depths in a first-person phenomenological perspective) or what happens among them (their social interactions, delicate communication patterns, etc.) in an 'objective' third-person perspective. The estimated figure of 20 percent being observable seems too high. However, Hattie and Zierer's statement that four-fifths 
of what happens-or even more-is not apparent to the professional teacher, nor graspable by his or her talent for interpretation, and far beyond his or her horizon of experience, legitimizes their cry for more research on visible learning - research that they themselves are ready and willing to conduct.

Therefore, my second philosophical argument emphasizes and critically reflects upon the important qualitative differences between first-order phenomenological 'inner sides' of learning (the pupil's being-in-the-world), the registered 'outer sides' of learning (the teacher's-being-in the-world-of-trying-to-estimate-and-maximize-pupils'-learning-outcomes surrounded by and taking part in wider-reaching power plays dominated by school leaders, political expectations towards education and, not least, economic competition), and scientifically transparent 'outer sides' (templates and proposals based on, for example, visible learning research). Do not forget that Hattie himself deals, primarily and explicitly, with visible learning for teachers [15].

These three 'worlds' are not equal and will probably never be reconciled or unified. They are, in fact, often engaged in both visible and invisible conflicts with one another as they do not share or honour mutual interests. The code and rationale for the pupil or student could be: do I get a high mark, does this subject interest me, and does the teacher notice and like me? The code and rationale for the teacher could be: can I produce the right test results, and will my leader notice and reward me as successful? The iconic and idealized code and rationale for research, meanwhile, is truth and nothing but the truth.

I will argue that educational scientists are destined and doomed to observe or to think about tensions and dilemmas within and between the three major 'agent' positions. Their codes and rationales differ dramatically. The visibility and invisibility of learning are complex phenomena and never something that can be treated as or reduced to already known factors of achievement.

One also has to take into consideration that ontology is not the same as epistemology [8]. Epistemology deals with conditions for knowing something about something-there can be no science without an epistemological foundation. The ontological foundation of human existence, by contrast, is a priori to science. Being a pupil-in-the-world and/or a teacher-in-the-world is never independent of context, qualities, emotions, experiences, hopes, dreams, anxieties, etc. The visible learning paradigm seems to ignore or, far too often, to produce a bad 'translation' of the profound enigmatic existential ontology. Therefore, it is blindfolding itself, all the while maintaining that epistemology's role is to fertilize and legitimize research 'results' and not to question the quality and possible flaws of scientific assumptions and predominant visibility procedures.

Furthermore, it is important to remember that the social communicative system-of the teacher, the school leader, the researcher, and / or the local or national educational policymaker-can never view the psychic system of the individual pupil or student. These two systems are not code-identical, nor are they transparent to one another, as the German sociologist Niklas Luhmann showed us many years ago [16] (Ch. 2). The two systems obey different logics and are in a way blind to each other's rationales.

\section{The Open and Enigmatic Plasticity of the Human Brain}

Let us now move to another field where there are great expectations when it comes to learning: the human brain and its powerful neuroplastic 'features' and potentials. It would, of course, be a dream come true for every educational planner and proponent of forward-looking visible learning agendas if we, once and for all, could solve the problem of how to measure learning and find the ideal metric, the 'gold standard', and pinpoint the centre of learning deep within the human brain. Then we could — so to speak—open it up and do our best to maximize and 'nurture' it.

My basic argument, however, is that we cannot see, nor measure, learning in the brain 1:1, even though contemporary brain scanning technologies are becoming highly advanced and cheaper to access, and even though attempts to provide the public with multi-coloured neuro-maps are very tempting. No one can examine the complex synaptic wiring process in the plastic, changeable and 'learning' brain, nor the body-phenomenological depths and growth of a human being, nor the diverse and expansive processes of all the contextual, historical social interactions around the learning process 
and reduce them to something simple and already 'known' (such as a figure, a score, an effect, an answer in a test, an evaluation statement, etc.).

We live in an era where there are high expectations for neuroscience, but much of this neuro-hype fosters neuro-myths. The brain is not something which we can control and decide what it should learn. Whether you think that learning has to do with rewiring synapses in the brain, social interaction or bodily cunning (i.e., both the corporeal experience and skills), this whole 'Westernized' and utmost competitive invested educational political idea of having an enforced learning agenda is misleading [17].

The brain consists of approximately 86 billion (a billion $=10^{9}$ ) neurons (brain cells), and each of these neurons can be wired to up to 10,000 other neurons. It is estimated that there are in the region of 13 trillion (a trillion $=10^{12}$ ) synapses (couplings and connections) in the brain. Even writing "are" is misleading, as humans and their brains are always in a process of becoming. (To try to develop an interdisciplinary scientific epistemology of this utmost dynamic process ontology of the plasticity of the brain-in-the-body-in-the-world is one of the major tasks and challenges of 21st century thinking.) The wiring takes place both before and after birth. To be human is to be engaged in a life-long rebirth.

This 'exorbitant' and almost unfathomable mathematics of the brain is not the only thing to take into consideration when we talk about the brain's plasticity in relation to learning. We have to remember that the brain is not an independent organ floating in a vat $[18,19]$. The brain is a mediating organ, an orchestra without a central conductor [20]. The brain is a part of the human body, and the complicated brain-body interaction cannot (and may never) be depicted-neither instantly nor as accumulated screenshots depicting every aspect of learning throughout an individual's entire lifespan in a direct perspective. Considering the enigmatic plastic human brain, 'just' try to imagine a mathematical equation with up to 13 trillion mutually interrelated 'unknowns', which also happen to be extremely flexible and unpredictable.

I, therefore, find it legitimate to assert that any attempt to locate and identify learning in the brain produces a myth of the existence of a common denominator for learning [21]. And every attempt to translate and reduce the complex neuroplasticity of the brain to simple messages is in vain-or even worse: fails to live up to or even violates the scientific norms scientists normally honour and respect. We also have to remember that brains do not go to school—whole, incarnated, situated, and thinking individual human beings go to school-nor do brains learn in and for themselves-humans learn, deeply embedded and embodied in complex existential, social, historical, educational, political and, not least, neuroplastic contexts and settings.

Should one have the ambition of scanning learning processes in situ and in actu in a school class for just one hour, it would not be enough to scan the individual pupil in splendid isolation. The whole class, including the teacher, would have to be placed in a giant scanner in order to be able to get data on all the linguistic, social and bodily interactions among the 20-40 people involved in one hour of highly invisible educational interactions. Besides the tough and probably insurmountable technical challenges of establishing such an experimental setting (should the people be held in individual tubes?), the wildest task would be to transform something such as $60 \times 20$ to $40 \times 13 \times 10^{12}$ synaptic 'learning' data into a trustworthy scientific language.

In addition, we should not forget Illeris's key definition: learning can be broadly defined as a permanent change in capacities. Therefore, the wild and demanding experiment described above would have to be repeated at least every school-year in order to say something (anything) about the possible permanence of learning. Taking into consideration that pupils might also learn outside the classroom-while surfing social media sites, talking to their parents, reading newspapers, playing football, daydreaming, writing love letters, getting a job, and having 2.4 children after leaving school-neuro-researchers actually need to perform an extensive scan of the entire population of the world to determine what learning is and could be. I wish them the best of luck! So far, John Hattie and his co-author Gregory Yates, a cognitive educational psychologist from the University of South Australia, have not been able to convince me that neuro-learning processes can be managed and 
transformed into a wilful field of intervention for designing neuro-enhancement processes in learning institutions [22].

From the perspective of knowledge politics, we stand on the threshold to a new world of thinking what the sciences can come to know and dwell upon. One might say that we enter a zone of indiscernibility-a bi-directional landscape in which to depict and decipher man situated between a 'neurobiologization' of the humanities and social sciences and a 'sociologization' of the neurosciences, as the Luhmannian sociologist Werner Vogd succinctly describes it in the book Gehirn und Gesellschaft [23]. Within the 'avant-garde' research of the neurosciences, it becomes ever more necessary to investigate the increasingly blurred borders between the neuronal dynamics, the phenomenological descriptions, the bodily motor activities and the interactive social processes and to transform them into legitimate fields in which new research exchanges can take place and fertile heretical questions take form [24].

Within the philosophy that we do not experience the world or our own bodily processes at the micro-level is an enduring practical phenomenological wisdom. We do not experience at the level of blood or skin cells and do not feel, or even notice, the neuronal activities (i.e., the formation of synapses, the wirings, the firings, etc.). We experience at other levels. We live among everyday macroscopic phenomena and know 'objects' such as neighbours, cars, teacups and roses. We use and understand symbols and sentences much better than we grasp the immune system, and we do not normally sense all the delicate (im)balances in our bacteriological flora. The human experience of the world is on a different scale and wavelength than biochemistry and neurophysiology.

If we further reflect upon this human condition, it must also be stressed that we do not experience the world on the largest macro-levels: the speed of light, the rotation of the planets, the existence of distant galaxies and black holes, the time span since the big bang, etc. These facts remain intangible abstractions. We, therefore, seem to be notorious 'in-betweeners' ('middle-beings'); we live in the midst of things. In everyday life, we are stretched out between the micro and macro universes, which thousands of researchers are engaged in scrutinizing, but we do not experience them as integral parts of our immediate existence. Facing autumn leaves and dead relatives, the first thought that comes to mind is not compost and putrefaction. Moreover, our neurons have no desire to read Friedrich Nietzsche's Götzen-Dämmerung - oder Wie man mit dem Hammer philosophiert (Twilight of Idols or, How to Philosophize with a Hammer) or to travel to an exotic beach next summer. Taking our human proportions into consideration, it is not surprising that most of us never deal with or sense our neurons and synapses [25] (p. 172f). Life is okay and worth living for the majority of us, even if we do not know how, where or if the 'I' can be located in the brain, and even though we are not co-present with, i.e., consciously aware of all the things that happen to and in us when we live and ... learn.

Let me try to summarize. The plasticity of the human brain is a precondition for learning, but it is always already embedded in delicate corporeal and sociological patterns. What goes on in the brain can never be directly depicted in the visible learning paradigm. Thinking is more than learning and learning is more than visible learning. The engaged existence needs far more than enhanced and institutionalized visible learning processes to be able to live and to think.

\section{Do Not Forget or Underestimate the Freedom of the Individual}

Thirdly, so-called visible learning for teachers [15] has to be differentiated from both conscious and unconscious learning for pupils and students [26]. What is visible for the teacher, or the 'tester', is not and can never be equal to the content of the complex learning processes 'in' and for pupils and students. Attempts to objectify and sometimes even instrumentalize learning risk running into obvious problems and fostering serious mistakes. Besides, the teacher and the 'learner' do not see the world in the same perspective, and they often also have different interests concerning both the didactical forms and the diverse subjects of the daily processes of education.

It is somewhat surprising that John Hattie-despite encouraging school 'actors' to listen to each other more closely rather than verbalizing sentences and syllables in splendid isolation—does not talk 
to the 'objects' of-and in-his influential research [10]. However, even if he, and other researchers he has influenced and inspired, had the chance to enforce the strategic idea that 'learners' should verbalize what they are doing while learning and then inscribe their 'results' into a personalised enhancement and achievement logic, it would be flawed in at least two ways. Firstly, 'learners' cannot know and/or detect precisely what has happened in their brains or in the embodied subjectivities (in their corporeal totality). Secondly, my argument is that, if the learning that is visible (to the teacher) is that which the pupil is able and willing to verbalize- that he or she can say "Now I have learnt this" - then that is but one tiny, self-reinforcing ('self-echoing') and restricted expression of a much larger picture.

What looks more and more like a global educational learning paradigm cannot be differentiated sharply from the visual (self-) technologies that have been used for ages in an effort to understand humans' 'inner' lives, based on the will of the (religious) authorities to detect their wrong, even dangerous, thoughts and actions. The evil wills and ways have to be deciphered and exposed.

In the third book of his Confessiones (Confessions), the early North African Church Father and Christian theologian and philosopher Aurelius Augustin states that the omniscient and omnipotent God observes and looks through me more intimately and from a higher level than I myself am capable of ever doing: interior intimo meo, superior summo meo [27] (quoted by Sloterdijk, p. 46). In his book Nach Gott—in German, meaning both after God and according to God—the philosopher Peter Sloterdijk analyses and reflects upon the tremendous power of the cultural and hermeneutical history of these maxims, 'preaching' "Dauerbeobachtung" and "Zwang zur Selbstbeobachtung" [27] (pp. 46-47), meaning permanent, penetrating observation (from above) and enforced and fragile self-observation (from within), desperately seeking to decipher the possibly fatal powerful 'glances' of God's earthly representatives and stand-in authorities.

Throughout the history of ideas, the heritage of God's capacity to be all-seeing (omnes videndes) has been profanized by luminous scientists, practical planners and politicians, and, more recently, by automated and decisive algorithms.

In education, many initiatives in recent years have sought to ' $x$-ray' pupils' and students' achievements, PISA-scores, well-being indexes, personal life narratives, etc. More than ever, it is difficult to hide from the ever-present learning-measurement regime. Teachers, school leaders, politicians, and educational economists—even parents—all want to "know thy impact" [28], and to accelerate student and pupil learning. Schools and universities are not seen as institutions for free spiritual and critical intellectual development $[13,29,30]$.

Instead of supporting the highly differentiated machinery of the prevalent forms of educational governance and biopolitical control over learning, and ignoring the fact that schools have always functioned as sorting mechanisms in a competitive society, one could turn to Karl Marx's extremely useful distinction between the use and the exchange value of the commodity. This idea, originally presented to a broader readership in the first volume of Das Kapital in 1867 [31], was recently re-conceptualized by the French philosopher and economist Yann Moulier Boutang in his book Cognitive Capitalism [17,32].

Even though subjectivity, in principle, is not something we can have or possess, but something that can be realized —-from time to time-in meetings and situations characterized by their novelty, openness and unpredictability—as Biesta writes in The Beautiful Risk of Education [33]—the 'production' of pupils' and students' subjectivities seems to be bifurcated according to the logic of the Marxian concept of the dual character of the labour force commodity in spe. As adults, human capital is given a price and its incarnated owner receives a salary (he or she has an exchange value). But that which is learned also has a use value for both the individual and society that can never be reduced to the human capital's price-token, i.e., the exchange value of the former learning accumulation within the educational system.

Seen from the perspective of the individual, the handling of the dual character of one's own labour force is also intimately related to the formation and edification of character (Bildung in German, cf. the section below). The task and challenge is not to dispose the quality and the employability of 
the entire labour force to the employer but to reserve major parts of it to the human being behind the employee mask. Bildung is the capacity and courage to determine how one's knowledge and skills can be used in ways that go far beyond what you are asked or expected and even often forced to do. Bildung has an inherent value, a personal style, and an irreplaceable form. The value of what you master and do manage to cope with can be used for both critical educational and trans-educational purposes in an emancipatory, power-challenging, and maybe even in an institution-transcending form.

Bildung is both an individual task and a societal obligation and challenge. Bildung is both the process and the result of the renunciation to be made stupid, short-sighted, and far too adaptive by the educational 'system' [34]. Bildung is to inject unexpected impressions, but also 'well-trained' and in best cases eloquent expressions into the social circulation of knowledge and to contribute to the continued communication, discovery and interpretation of mankind.

Bildung is learning to take care of oneself but at the same time the will to dare to transcend one's own perspective. But first and foremost, Bildung is exercise, exercise, exercise ...practice, practice, practice-beyond fear and mandatory learning goals [35] (p. 113).

\section{In Defence of Bildung — and the Dialectics between Extension and Incarnation}

When I started school back in 1965, no one talked about learning (in Danish: læring). It was a foreign word. The teachers and the parents talked about homework and teaching. The normal Danish word for being taught, and thereby for the desired outcome of teaching, in those days was indlæring (literally translated: in-learning), implying a top-down injection of knowledge into more or less empty containers or writing on blank slates, as two of the established and widespread metaphors put it. Furthermore, primary school was not part of the educational system. The word education was reserved for the processes through which you obtained the skilled qualifications as a blacksmith, carpenter, cook, nurse, etc., after school. The in-principle mandatory year 0-18 educational OECD continuum was not 'invented' yet, neither did education have its take-off in the kindergarten-being seen as the first, important and inevitable part of the food chain, as the European Commission proclaimed in 2011 [36] (p. 1)-but that is another story [35] (p. 14).

The concept of learning entered the Danish context during the 1960s and 1970s as a word explicitly criticizing undemocratic educational top-down decisions and traditional and enforced socialization patterns within education. In those days, the learning agenda was critical towards what was seen as an authoritarian and conservative codified learning monopoly and demanded autonomy, problem-oriented study and group work, interdisciplinary approaches, social relevance and personal motivation. Critical educationalists studied and revitalized the 'old' texts of the American philosopher John Dewey and the German didactical pedagogical theoretician Wolfgang Klafki-and the Germans and Danes developed several types of "Reform Pädagogik" (reform pedagogy) and 'implemented' them in state-supported school experiments [37].

From the 1990s and onwards, the learning paradigm became embedded in the institutional self-understanding and curricula of the Danish education system. The learning paradigm became radically transformed from being an emancipatory term to be a part of the establishment and the rhetoric of the winners. One might say that the learning paradigm was absorbed by the merciless logic of capitalism.

International economists, politicians, and researchers began to argue that dynamic capitalism presented a need for lifelong learning, from the cradle to the grave, rather than the transfer of knowledge and acquisition of clearly defined skills $[17,32]$. Mass education should ideally produce self-reflective, flexible citizens, ready and willing to learn. As self-substantiated subjects, the learners are not taught but supervised (i.e., have their learning facilitated). They write their own cardinal questions to self-chosen problem-based study projects, find their own literature, and design their own learning process. They have to find their own level of ambition while being transformed from disciplined subjects to responsible learning agents. One could also say that the pupils and students are governed through, with and by freedom and attempts to realize their potentials. 
Today, there is no longer any criticism or revolt hidden in the concept of learning. Learning has become an inescapable and ubiquitous condition, and a 'natural' claim in the intensified competition to have the most creative workforce, the most profitable innovation, the most exciting life, the highest level of well-being, and the coolest jobs. Learning goals become mandatory in curriculum policy texts, and institutions, companies, and even countries have to become learning organizations and communities. No individual can authoritatively proclaim that he has learned all that can be learned or is worth learning. The simultaneous demand for 'developmentalism' (you must constantly develop if you do not want to become complacent and 'die') makes learning a necessary lubricant.

All in all, the concept of learning is by no means an unproblematic or value-neutral term. It should be used with an awareness of its historical development as a concept and its usage in educational policy. Let us, therefore, now set learning as a concept to one side and shift gear. I will now try to argue through illustration that the formation of the character (Bildung in light of the rich German geisteswissenschaftliche tradition) and the capability to think and become a vivid language user and creator demand much more than learning. Moreover, teaching is much more than a method to 'produce' learning, and the purpose of education must transcend a teleological implementation of strategic national and international learning goals [9]. Man is created in God's image (in German: Bild), so the 'holy' Bible says (Genesis 1.22), so the concept of Bildung has long and vividly contested theological roots, but in the profane world of today it is of utmost importance to learn(!) to see oneself as something other than a strategic agent in the mirror of formation. If you only see your reflection in the mirror, and nothing exterior, you paradoxically hinder your own self-formation process in the face of static non-movement. Short-sightedness and strategic-instrumental self-centredness might risk destroying and limiting pupils' and students' access to the unknown. As a teacher, therefore, you must do your best to serve and foster the art of decentring from Monday to Friday, week after week, year after year.

Edification of character (Bildung) signifies many 'things'; but people, in their desire to avoid being stupid by making hasty decisions, desire it. Both edification and its practical cousin, education, can foster an intensified attentiveness and help in distancing oneself from any hasty, careless, and nasty brutalization of thought, speech, and action. Edification is a word of opposition and critique. Edification is provided through exercises, not least exercises of wonder [26]. Character formation (another attempt to translate Bildung) is related to ideas about the grand words of enlightenment, authority, knowledge, wisdom, autonomous thinking, and aesthetic judgment as well as the critique of language and contemporary society [13].

Furthermore, the contemporary attempts to revitalize Bildung are, of course, made possible by the rich reception history (Hans-Georg Gadamer called it Wirkungsgeschichte) in which we are living, interpreting, and 'breathing'. The telos of a revitalized concept of Bildung and its related praxis is to be able to inherit from-and, ideally transcend-Humboldt, Herder, Kant, Hegel, Schlegel, Nietzsche, Critical Theory, hermeneutics, phenomenology, and the history of the concepts (in German: Begriffsgeschichte) in order to create new ways of thinking and acting.

Bildung is so much more than education. Character formation cannot be operationalized or formalized, much to the dismay of educational bean counters, cost reducers, changing ministers and state and municipal education planners. It is, in principle, also liberated from the constraining neurotic arrays of learning, utilitarian calculations and statistical exercises concerning labour market trends and the overly servile competitive nation state behaviour. Bildung belongs to life. It is autonomous, auto-telic, and possesses its own reasons, such as art, joy and love.

As an alternative to the predominant Hattian perspective on visible learning, my view and argument is that every time you learn something, you, both consciously and unconsciously, both visibly and invisibly, incarnate it in your bodily being and not only in your 'inner' mental cognitive structure [26]. And every time you incarnate something that is worthy of incarnation, you extend your bodily and mental synthesis [38,39]. That means you now better understand the world and gain a wider range of action and freedom-grasping and experiencing more of what life can offer you. As such, a bi-directional movement exists between incarnation and extension, and it is of utmost 
importance for the development of you as a person, a rich being-in-the-world. Based on my own 60 years of life experience and not least the inspiration I draw from the German body-phenomenologist, philosopher and psychiatrist Thomas Fuchs and his great book Ecology of the Brain [19], the human movement can be described as an embodied, embedded, and enacted knowledge and experience and it is expressed and sensed via incarnation-extension dialectics.

Incarnation-extension dialectics and the revitalized Bildung concept could most likely also be described as my attempt-from the sidelines-to renew the widely abused, very unclear and semantically virtually drained concept of learning. (But it should of course not be forgotten nor repressed that the concept of Bildung is highly contested. My Bildung credo has to be strengthened and solidified. Preliminary attempts to do so can be found in $[13,30,34,35]$.

\section{Blindness in Seeing and Not Seeing}

As I near the end of this article, my argument is that there are major 'innate' obstacles to visibility and to the visible learning paradigm. Blindness is an inevitable part of educational seeing. The powerful scientific and political adherents of learning cannot see what they cannot see-neither when they see what they (think they) see, nor when they do not see what they do not (want to) see.

In his late-career meta-reflexive and eye-opening two volume oeuvre Die Gesellschaft der Gesellschaft (literally translated: The Society of Society. In English the title is: Theory of Society. Volume 1 and 2. Stanford: Stanford University Press (2012 and 2013). Niklas Luhmann states that it is completely unrealistic for an individual to know what (s)he does not know [40] (p. 39). (One could also study Gregory Bateson's systemic theory of learning and the double-bind dilemmas in regard to the question of blindness in seeing. Luhmann is a clear-sighted thinker but only one option and source of inspiration.) Thirty pages later, he argues that the observer ("Beobachter" in German) does not see himself while observing (in German: "kann sich selbst beim Beobachten nicht sehen") [40] (p. 69). Therefore, every observation is based on a blind spot (in German: "blinder Fleck").

The condition for and of seeing is that you establish a distinction between seeing and not-seeing [40] (p. 70). Another profound assertion of Luhmann's is: "Auch alle Selbstbeobachtung ist ja bedingt durch einen blinden Fleck. Sie ist nur möglich, weil sie ihr Sehen nicht sehen kann" [40] (p. 81, pp. 165, p. 178). A paraphrased and condensed translation could be: "All self-observation is due to a blind spot. It is only possible insofar it cannot see itself seeing".

If the 'inventors' and followers of the visible learning paradigm forget these fundamental, modest, critical, and important Luhmannian remarks, they risk supporting a 'production' of a borderless hyper-positive visibility ideology and piling up limited data that contribute to vast ocular-centred simulations.

The purpose of education is much more demanding and challenging than enhancing visible learning processes and results (see Hattie and Larsen in [10]).

Funding: This research received no external funding.

Conflicts of Interest: The author declares no conflict of interest.

\section{References}

1. Hattie, J.; Masters, D.; Birch, K. Visible Learning into Action. In International Case Studies of Impact; Routledge: New York, NY, USA, 2015.

2. Hattie, J. Visible Learning: A Synthesis of over 800 Meta-Analyses Relating to Achievement; Routledge: New York, NY, USA, 2009.

3. Larsen, S.N. Blind Spots in John Hattie's Evidence Credo. J. Academ. Perspectiv. 2015, 1. Available online: http://www.journalofacademicperspectives.com/back-issues/volume-2015/volume-2015-no-1/ (accessed on 23 February 2019).

4. Skovmand, K. Uden Mål og Med—Forenklede Fælles Mål? Hans Reitzels Forlag: København, Denmark, 2016. 
5. Skovmand, K. I Bund og Grund-Reformer Uden Fundament? Hans Reitzels Forlag: København, Denmark, 2019.

6. Skovmand, K. Folkeskolen—Efter Læringsmålstyringen? Hans Reitzels Forlag: København, Denmark, 2019.

7. Larsen, S.N.; Pedersen, I.K. (Eds.) Sociologisk Leksikon; Hans Reitzels Forlag: Copenhagen, Denmark, 2011.

8. Larsen, S.N. A critical essay on the exercise of critique. On the impossibility of reconciling ontology and epistemology. Dan. Yearb. Philos. 2018, 51, 119-141.

9. Biesta, G. The Rediscovery of Teaching; Routledge: New York, NY, USA, 2017.

10. Hattie, J.; Larsen, S.N. The Purpose of Education-A conversation between John Hattie and Steen Nepper Larsen. Unpublished work. 2019.

11. Schleicher, A. Megatrends: Students' and teachers' future competencies. Recommendations for educational policy and practice. In Proceedings of the Improving Schools through an International Outlook, Danish School of Education, Copenhagen, Denmark, 4 October 2018.

12. Fadel, C.; Bialik, M.; Trilling, B. Four-Dimensional Education: The Competencies Learners Need to Succeed; Center for Curriculum Redesign: Boston, MA, USA, 2015.

13. Larsen, S.N. Top-Down University Governance Eradicates Thinking and Good Teaching. In On the facilitation of the Academy; Westergaard, E., Wiewiura, J.S., Eds.; Rotterdam, The Netherlands, 2015. Available online: https:/ / www.sensepublishers.com/media/2288-on-the-facilitation-of-the-academy.pdf (accessed on 23 February 2019).

14. Hattie, J.; Zierer, K. 10 Mindframes for Visible Learning. Teaching for Success; Routledge: New York, NY, USA, 2018.

15. Hattie, J. Visible Learning for Teachers: Maximizing Impact on Learning; Routledge: New York, NY, USA, 2012.

16. Luhmann, N. Die Erziehungssystem der Gesellschaft; Suhrkamp Verlag: Frankfurt am Main, Germany, 2002.

17. Larsen, S.N. Compulsory Creativity-a Critique of Contemporary Cognitive Capitalism. Culture Unbound 2014, 6. Available online: http:/ / www.cultureunbound.ep.liu.se/v6/a09/cu14v6a09.pdf (accessed on 23 February 2019).

18. Sheets-Johnstone, M. The Roots of Thinking; Template University Press: Philadelphia, PA, USA, 1990.

19. Fuchs, T. Ecology of the Brain. The Phenomenology and Biology of the Embodied Mind; Oxford University Press: Oxford, UK, 2018.

20. Fuchs, T. Das Gehirn—ein Beziehungsorgan. Eine phänomenologisch-ökologische Konzeption; Verlag Kohlhammer: Stuttgart, Germany, 2009.

21. Fuchs, T. Neuromythologien. Mutmaßungen über die Bewegkräfte der Hirnforschung. Jahrbuch für Psychotherapie Philosophie Philosophie und Kultur 2006, 1.

22. Hattie, J.; Yates, G. Visible Learning and the Science of How We Learn; Routledge: New York, NY, USA, 2014.

23. Vogd, V. Gehirn und Gesellschaft; Velbrück Wissenschaft: Weilerswist, Germany, 2009.

24. Larsen, S.N. The Plasticity of the Brain-An Analysis of the Contemporary Taste for and Limits to Neuroplasticity; Neurolex Dura Lex: Wellington, New Zealand, 2013. Available online: http:/ / www.victoria.ac.nz/law/ nzacl/PDFS/SPECIAL\%20ISSUES/NEUROLEX/CP\%20Neurolex\%20Book\%20Web\%20All.pdf (accessed on 23 February 2019).

25. Hoffstadter, D. I Am a Strange Loop; Basic Books: New York, NY, USA, 2007.

26. Kauffmann, O. Usynlig læring. Turbulens. 2017. Available online: http://turbulens.net/usynlig-laering/ (accessed on 23 February 2019).

27. Sloterdijk, P. Nach Gott; Suhrkamp Verlag: Berlin, Germany, 2017.

28. Hattie, J. Know Thy Impact: Visible Learning in Theory and Practice; Routledge: New York, NY, USA, 2012.

29. Ingold, T. The Manifesto. Reclaiming our University. Aberdeen University. 2016. Available online: https: / / reclaimingouruniversity.files.wordpress.com/2016/10/reclaiming-manifestofinal.pdf (accessed on 23 February 2019).

30. Larsen, S.N. What is education?-a critical essay. In What is Education? Jørgensen, A.B., Ed.; DUF/Problema: Copenhagen, Denmark, 2017; pp. 157-186. Available online: http:/ / www.whatiseducation.net/wp-content/ uploads/2017/09/what-is-education.pdf (accessed on 23 February 2019).

31. Marx, K. Capital: A Critique of Political Economy; Progress Publishers, Moscow, USSR: Harmondsworth, UK, 1867.

32. Moulier Boutang, Y. Cognitive Capitalism; Polity Press: Cambridge, UK, 2007/2011.

33. Biesta, G. The Beautiful Risk of Education; Routledge: New York, NY, USA, 2013. 
34. Koselleck, R. Zur anthropologischen und semantischen Struktur der Bildung. In Begriffsgeschichten. Studien zur Semantik und Pragmatik der Politischen und Sozialen Sprache; Suhrkamp Verlag: Frankfurt am Main, Germany, 2006.

35. Larsen, S.N. At Ville Noget Med Nogen. Filosofiske og Samtidskritiske Fragmenter om Dannelse og Pædagogik; Turbine: Aarhus, Denmark, 2016.

36. European Commission. Early Childhood Education and Care: Providing All Our Children with the Best Start for the World of Tomorrow. Communication from the Commission 17.2.2011. Com 66. 2011. Available online: https:/ / eur-lex.europa.eu/legal-content/EN/TXT/PDF/?uri=CELEX:52011DC0066\&from=CS (accessed on 23 February 2019).

37. Larsen, S.N. Efterskrift: Hvordan undgå at læring bliver til en kliché? In Læring i Daginstitutioner-et Erobringsprojekt; Dafolo Forlag: Frederikshavn, Denmark, 2014; pp. 171-184.

38. Fuchs, T.; de Jaegher, H. Enactive intersubjectivity: Participatory sense-making and mutual incorporation. Phenomenol. Cognit. Sci. 2009, 8, 465-486. Available online: http://www.klinikum.uni-heidelberg.de/ fileadmin/zpm/psychatrie/fuchs/Enactive_Intersubjectivity.pdf (accessed on 23 February 2019).

39. Sheets-Johnstone, M. The Corporeal Turn. An Interdisciplinary Reader; Imprint Academic: Exeter, UK, 2009.

40. Luhmann, N. Die Gesellschaft der Gesellschaft 1; Suhrkamp Verlag: Frankfurt am Main, Germany, 1998.

(C) 2019 by the author. Licensee MDPI, Basel, Switzerland. This article is an open access article distributed under the terms and conditions of the Creative Commons Attribution (CC BY) license (http://creativecommons.org/licenses/by/4.0/). 